https://dx.doi.org/10.4314/ijs.v22i3.7

Ife Journal of Science vol. 22, no. 3 (2020)

\title{
MORPHOLOGICAL CHARACTERIZATION OF NATURAL POPULATIONS OF Sarotherodon galilaeus (LINNAEUS, 1758) FROM THREE SELECTED RESERVOIRS IN SOUTH WESTERN, NIGERIA
}

\author{
$*^{1}$ Oladimeji, T. E., ${ }^{1}$ Awodiran, M. O. and ${ }^{2}$ Ola-Oladimeji, F. A. \\ ${ }^{1}$ Department of Zoology, Obafemi Awolowo University, Ile-Ife, Nigeria. \\ ${ }^{2}$ Department of Zoology and Environmental Biology, Ekiti State University, Ado-Ekiti, Nigeria. \\ Email addresses of authors: OTE-tofunmioladimeji9@gmail.com; AMO-michfemi@yahoo.com; OFA- \\ folasade.majolagbe@eksu.edu.ng.*Corresponding author. \\ (Received: $3^{\text {rd }}$ August, 2020; Accepted: $25^{\text {th }}$ September, 2020)
}

\section{ABSTRACT}

\begin{abstract}
Morphological characterization of Sarotherodon galilaeus (Linnaeus, 1758) from Opa, Asejire and Ero reservoirs in southwest, Nigeria was carried out with a view to determining the morphological heterogeneity or homogeneity among the three different populations and to determine whether there are morphotypes of this species in the selected study areas. Twenty five morphometric measurements and six meristic counts were recorded on 150 specimens; fifty from each reservoir population. Principal Component Analysis (PCA) and Canonical Variate Analysis (CVA) were performed on the morphometric and meristic data using PAST software. All the clusters produced by the PCA and CVA analyses on the morphometric and meristic data overlapped widely; indicating a low level of morphological differentiation among the three populations of Sarotherodon galilaeus. The study concluded that the Sarotherodon galilaeus populations from Opa, Asejire and Ero reservoirs are morphologically similar and phenotypically inseparable.
\end{abstract}

Keywords: Morphometric, Meristic, Morphological differentiation, Reservoirs in south-western Nigeria, Sarotherodon galilaeus

\section{INTRODUCTION}

One of the major forces that drive the evolution of new species is the formation of different morphotypes within a population; which is induced by both biotic and abiotic conditions of the environment. The degree of speciation can be assessed directly by quantifying the morphological traits both morphometric and meristic characters of individuals within the population (Bailey, 1997). Morphometric characters are external features that are quantified using metric measurements in form of size; they can also be quantified geometrically in form of shape; while meristic characters are quantified using serial body counts.

It has been documented in several species that there is a strong correlation between morphology and habitat specialization; as morphological traits that are well suited to the conditions in one environment may be ill-suited to those in others (Bolnick et al., 2003; DeWitt and Scheiner, 2004; Webster et al., 2011). Little variation in body shape has been seen to correlate with fitness parameters such as body condition, foraging success, growth rate etc. Lindsey (1988) noted that morphology is particularly dependent on environmental conditions especially, during early life history stages. The prevailing environmental conditions during the early developmental stages of an organism, shapes and influences largely the morphology and phenotype of that organism (Tudela, 1999; Pinheiro et al., 2005). Morphological characteristics can show high flexibility in response to differences in environmental conditions (Swain and Foote, 1999) which may lead to adaptive selection. This implies that organisms in a population may adjust their morphological features to meet the peculiarities and demand of their ecological conditions (Swain and Foote, 1999). Stearns (1983) noted that fishes exhibit some degree of phenotypic plasticity which allows them to respond adaptively to environmental changes.

In fisheries biology, morphometric and meristic characters have been commonly used as powerful tools for measuring discreteness and relationships among various taxonomic categories (Ihssen et al., 1981). They are also used to identify fish stocks (Turan et al., 2006; Suneetha and Damayanthi, 2008) and for determining the evolutionary linkages between fish fauna (Deesri et al., 2009). Information on morphological variation among 
populations can serve as a basis for studying population structure, and may be useful for studying short-term, environmentally- induced variations directed towards effective management of fisheries. Intra-specific morphological variations corresponding to differences in habitat and resource use have been documented in different animal groups, including gastropods (De Witt et al., 2000), insects (Johansson and Wahlstrom, 2002); amphibians (Dayton et al., 2005); reptiles (Phillips and Shine 2004); birds (Price, 1987) and mammals (Smartt and Lemen, 1980). In fishes, intraspecific morphological variation within and among populations with similar and different environmental conditions including water chemistry, substrate type and water depth has been reported by several authors (Lattuca et al., 2007; Spoljaric and Reimchen, 2007; Oladimeji et al., 2015; Solomon et al., 2015; Oladimeji and Olaosebikan, 2017). Although, reports have suggested that the morphological characteristics of fish are determined by an interaction between both genetic and environmental factors (Tudela, 1999), it has been observed that morphological variability among populations may not necessarily reflect population differentiation at the molecular level (Tudela, 1999). At the intra-specific level, phenotypic differences observed in morphological characters are not directly under the influence of genes, but is subjected to environmental modification (Khayyami et al., 2015).

Sarotherodon galilaeus, is native to Africa and Middle East, but is widely distributed also in Europe and some parts of America. It has been introduced to several Asian countries such as Japan and China for aquaculture purposes (Froese and Pauly, 2014). S. galilaeus is largely found in Nigerian waters; it is widely cultivated and appreciated by consumers because of its excellent taste and being a good and affordable source of protein. There is paucity of information on the morphological characterization of wild populations of S. galilaeus in southwestern Nigeria and there is need to determine whether there are morphotypes of these species especially in the selected study areas where large and indiscriminate harvest of this fish is done on daily basis. This information will contribute to knowledge on the taxonomy of this fish species and by extension; ensure its effective management, sustainable yield and conservation.

\section{MATERIALS AND METHODS STUDY AREA}

The fish samples were collected from three reservoirs located in three different states (Osun, Oyo, and Ekiti States) in the southwestern part of Nigeria. The reservoirs are Opa reservoir in Osun state, Asejire reservoir in Oyo state and Ero reservoir in Ekiti state. These three reservoirs represent some of the major water bodies in southwestern Nigeria, where large harvest of this fish species is done on daily basis. The Opa Reservoir Basin was established in 1978 by the impoundment of Opa River which took its source from Oke-Opa Hills. It is geographically located in Ile-Ife, Osun state, Nigeria. The reservoir has a catchment area of close to 116 square kilometres. It extends from longitude $4^{\circ} 31^{\prime} \mathrm{E}$ to $4^{\circ} 39^{\prime} \mathrm{E}$ and from latitude $7^{\circ} 21^{\prime} \mathrm{N}$ to $7^{\circ} 35^{\prime} \mathrm{N}$ (Figure 1). The surface area of the reservoir is about 0.95 square kilometres, while the capacity at peak level is about $675 \mathrm{~m}^{3}$. The minimum depth is $0.95 \mathrm{~m}$ while the maximum depth is $6.4 \mathrm{~m}$. The mean annual temperature of the area is $27^{\circ} \mathrm{C}$ (Akinbuwa and Adeniyi, 1996).

Asejire Reservoir is located in Oyo State, in the southwestern part of Nigeria. It is the impoundment of the Osun River, about 30 kilometres east of Ibadan (Figure 2). It lies between latitude $7^{\circ} 21^{\prime} 45^{\prime \prime} \mathrm{N}$ and longitude $4^{\circ} 08^{\prime} 00^{\prime \prime} \mathrm{E}$. It has a catchment area of about 23.42 $\mathrm{km}^{2}$ (2,342 hectares), a normal pool elevation of $150 \mathrm{~m}$ and maximum flood elevation of $152.4 \mathrm{~m}$. The surface area is about $24 \mathrm{~km}^{2}$ (Ayodele, 1979). The reservoir provides water to the Asejire and Osegere water treatment plants in Ibadan. It has a capacity of about 80 million litres per day, of which $80 \%$ is used for domestic purposes.

Ero Reservoir, established in 1983, is located in Ikun-Ekiti, Ekiti state, Nigeria. It is the impoundment of the Ero River which lies between latitude $7^{\circ} 59^{\prime} \mathrm{N}$ and longitude $5^{\circ} 12^{\prime} \mathrm{E}$, covering a distance of about $11 \mathrm{~km}$ (Figure 3 ). The impoundment area is about $4.5 \mathrm{~km}^{2}$ while the water surface area is about 450 hectares with a maximum capacity of about 20.9 million cubic 
metres. The dam supplies over one hundred towns and villages in the state with pipe borne water

(Omoniyi and Basorun, 2013).

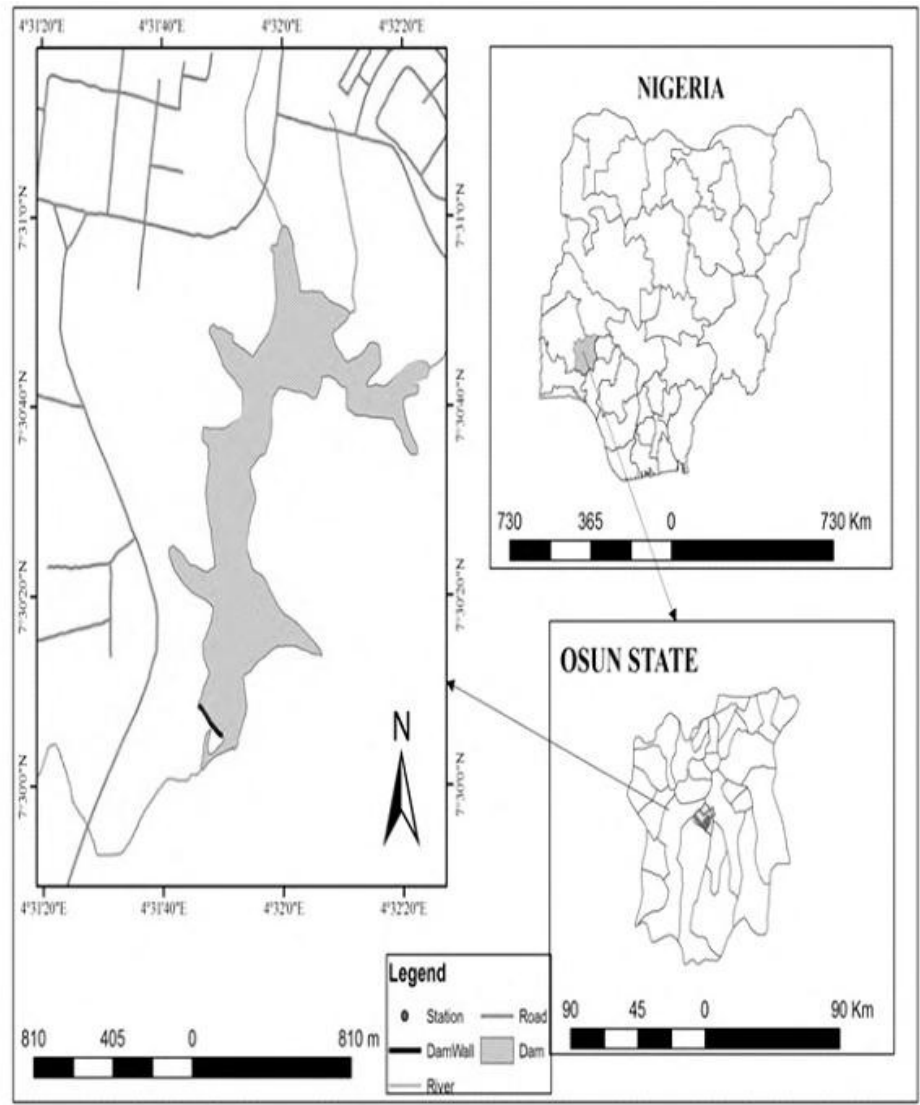

Figure 1: Map of Opa Reservoir in Osun State, Nigeria

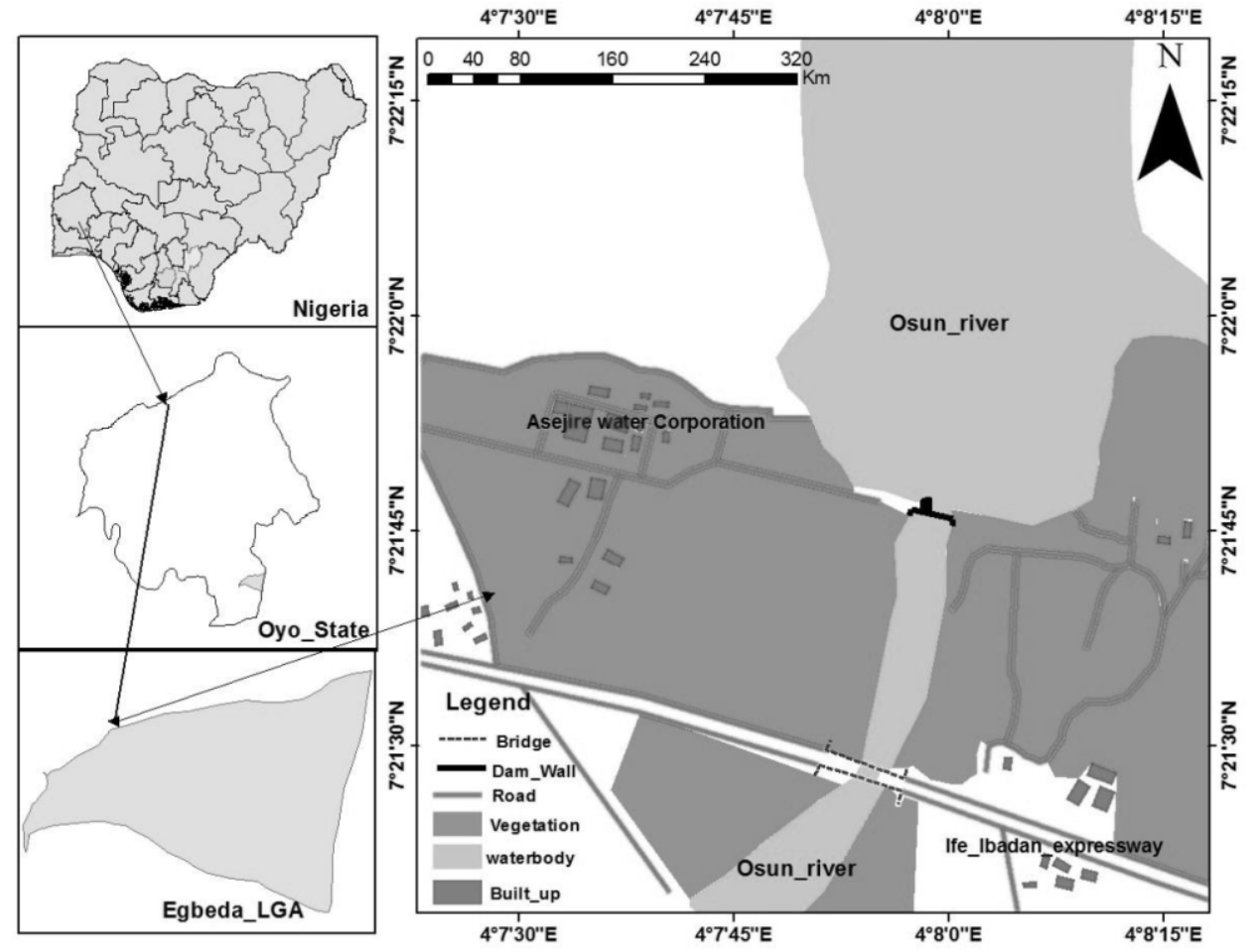

Figure 2: Map of Asejire Reservoir in Oyo State, Nigeria 

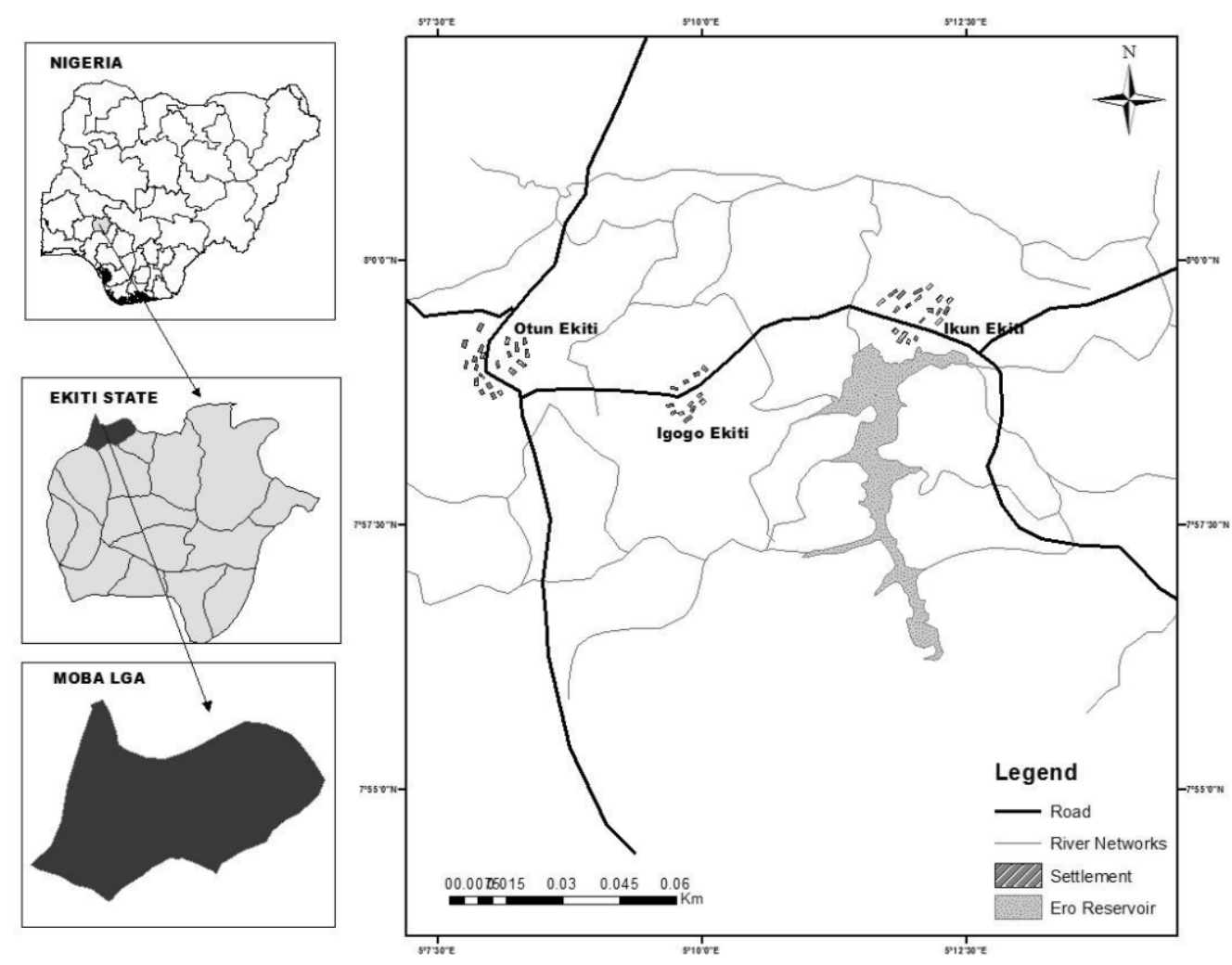

Figure 3: Map of Ero Reservoir in Ekiti State, Nigeria

\section{Sampling}

Fifty samples of $S$. galilaeus were randomly collected from each reservoir; making a total of 150 samples. The fish samples were collected from landings of commercial fishermen at each study site and then brought to the Fish Culture Laboratory in the Department of Zoology, Obafemi Awolowo University. The fish samples were identified using standard identification key prepared by Paugy et al. (2003). Twenty five morphometric measurements [Total length (TL), Standard length (SL), Head length (HL), Body depth (BD), Snout length (SNL), Cheek depth (CHD), Eye length (EYL), Dorsal fin length (DFL), Anal fin length (AFL), Length of last dorsal spine (LDS), Length of third anal spine (LTAS), Pelvic fin length (PFL), Pre-dorsal distance (PDD), Upper lip length (ULL), Lower jaw length (LJL), Lower lip width (LLW), Lower lip length (LLL), Pectoral fin length (PECFL), Pre-orbital distance (POD), Caudal peduncle length (CPL), Caudal peduncle depth (CPD), Lower jaw width (LJW), Pelvic spine length (PSL), Pre-anal distance (PAD) and Distance of lower jaw to pelvic fin (PELD)] as in Dunz and Schliewen (2010) and were recorded in 50 individuals in each population using digital
Vernier calliper (NEIKO 01407A). Six meristic counts: number of scales on lateral line, number of dorsal spine, number of dorsal ray, number of gill rakers, number of anal fin rays and number of anal fin spines were also recorded. Principal Component Analysis and Canonical Variate Analysis were carried out separately on the morphometric measurements and meristic counts because morphometric characters are continuous while the meristic characters are discontinuous. Furthermore, the meristic characters are fixed early in development while the morphometric characters are more prone to environmental changes (Allendorf et al., 1987). Measurements of each morphometric character were standardized for fish size (SL) in accordance with Reist (1985) using percentage standard length as follows:

$\mathrm{Mn}=(\mathrm{Mo} / \mathrm{SL}) \%$,

where: Mo is the original measurement; and SL is the standard length.

This was done in order to remove the varying effect of size on each of the fish samples.

Size-corrected morphometric data were analysed by multivariate method using Principal Component Analysis (PCA) and Canonical Variate Analysis (CVA) on Paleontological 
Statistics (PAST) software (Hammer et al., 2001). Canonical Variate Analysis was done specifically to test for intraspecific variation within the populations. Factor loadings based on Eigen values from Principal Component Analysis (PCA) were used to determine the morphometric character with the highest variation that can discriminate among the three populations. The meristic data were also subjected to Principal Component Analysis while factor loadings based on Eigen values was also used to identify the meristic character that differed most among the three populations.

\section{RESULTS}

The descriptive statistics of each morphometric and meristic characters recorded on the $S$. galilaeus samples are shown on table 1 . The PCA showed a wide overlap of data among the morphometric measurements of $S$. galilaeus from the three reservoirs (Figure 4). Canonical Variate Analysis (CVA) plot also showed a marked overlap of morphometric data among members in Ero, Opa and Asejire reservoir respectively, however there is a slight dispersion from the cluster by members occupying Opa reservoir (Figure 5). Factor loadings based on Eigen values from the PCA showed that dorsal fin length was the morphometric character that varied most among the three populations and hence can be used to delineate the populations. The PCA based on the six meristic counts of S. galilaeus from Opa, Asejire and Ero reservoirs in Osun, Oyo and Ekiti states respectively showed homogeneity as the meristic characters largely overlapped among the three populations (Figure 6). However, factor loadings based on Eigen values on the PCA was able to identify number of gill rakers as the meristic character most responsible for variation among the studied populations (Figure 7). 
Table 1: Descriptive Statistics of the Morphological Traits Recorded on Sarotherodon galilaeus from Ero, Opa and Asejire Reservoirs in South-western Nigeria

\begin{tabular}{|c|c|c|c|c|c|}
\hline $\begin{array}{l}\text { Morphometric } \\
\text { and Meristic } \\
\text { parameters }\end{array}$ & Mean & $\begin{array}{l}\text { Std. } \\
\text { Deviation }\end{array}$ & $\begin{array}{l}95 \% \text { C.I. } \\
\text { of mean }\end{array}$ & Max. & Min. \\
\hline \multirow{3}{*}{$\begin{array}{ll}\text { TL } & \text { ERO } \\
& \text { OPA } \\
& \text { ASEJIRE }\end{array}$} & 11.758 & 1.791 & 0.509 & 16.90 & 9.20 \\
\hline & 18.120 & 4.902 & 1.393 & 30.90 & 11.40 \\
\hline & 13.906 & 1.618 & 0.460 & 0.50 & 10.50 \\
\hline SL ERO & 9.092 & 1.524 & 0.433 & 13.70 & 6.90 \\
\hline OPA & 14.688 & 4.263 & 1.212 & 24.90 & 8.80 \\
\hline ASEJIRE & $11 . .078$ & 1.346 & 0.382 & 17.00 & 8.50 \\
\hline \multirow{3}{*}{$\begin{array}{ll}\text { HL } & \text { ERO } \\
& \text { OPA } \\
& \text { ASEJIRE }\end{array}$} & 3.446 & 0.677 & 0.192 & 5.00 & 2.20 \\
\hline & 4.710 & 1.054 & 0.300 & 8.40 & 3.40 \\
\hline & 3.832 & 0.463 & 0.131 & 5.60 & 3.00 \\
\hline \multirow{3}{*}{$\begin{array}{ll}\text { BD } & \text { ERO } \\
& \text { OPA } \\
& \text { ASEJIRE }\end{array}$} & 4.006 & 0.757 & 0.215 & 5.60 & 2.80 \\
\hline & 6.578 & 1.884 & 0.535 & 11.90 & 4.20 \\
\hline & 4.482 & 0.514 & 0.146 & 6.50 & 3.60 \\
\hline SNL ERO & 1.060 & 0.384 & 0.109 & 2.30 & 0.40 \\
\hline OPA & 2.074 & 3.190 & 0.907 & 24.00 & 0.90 \\
\hline ASEJIRE & 1.224 & 0.196 & 0.0558 & 1.90 & 0.80 \\
\hline \multirow{3}{*}{$\begin{array}{ll}\text { CD ERO } \\
\text { OPA } \\
\text { ASEJIRE }\end{array}$} & 1.372 & 0.513 & 0.146 & 3.40 & 0.60 \\
\hline & 2.106 & 2.225 & 0.632 & 17.00 & 1.00 \\
\hline & 1.584 & 1.658 & 0.471 & 13.00 & 1.00 \\
\hline \multirow{3}{*}{$\begin{array}{ll}\text { EL } & \text { ERO } \\
& \text { OPA } \\
& \text { ASEJIRE }\end{array}$} & 1.214 & 1.440 & 0.409 & 11.10 & 0.40 \\
\hline & 1.126 & 0.265 & 0.0753 & 1.90 & 0.50 \\
\hline & 1.008 & 0.110 & 0.0314 & 1.20 & 0.70 \\
\hline DFL ERO & 6.094 & 0.734 & 0.208 & 9.30 & 5.00 \\
\hline OPA & 8.894 & 7.516 & 2.136 & 58.00 & 1.60 \\
\hline \multirow{2}{*}{$\begin{array}{l}\text { ASEJIRE } \\
\text { AFL ERO }\end{array}$} & 4.726 & 0.877 & 0.249 & 7.60 & 3.00 \\
\hline & 1.424 & 0.337 & 0.0958 & 2.30 & 0.40 \\
\hline OPA & 2.716 & 0.881 & 0.250 & 4.80 & 1.20 \\
\hline ASEJIRE & 1.932 & 0.327 & 0.0930 & 2.90 & 1.40 \\
\hline LDS ERO & 1.812 & 0.245 & 0.0698 & 2.50 & 1.30 \\
\hline OPA & 2.740 & 2.861 & 0.813 & 22.00 & 1.40 \\
\hline ASEJIRE & 1.412 & 0.340 & 0.0967 & 2.10 & 0.70 \\
\hline LAS ERO & 1.150 & 0.320 & 0.0908 & 2.00 & 0.50 \\
\hline OPA & 1.722 & 0.505 & 0.144 & 2.70 & 0.60 \\
\hline ASEJIRE & 1.652 & 0.219 & 0.0622 & 2.30 & 1.20 \\
\hline PFL ERO & 2.544 & 0.556 & 0.158 & 4.30 & 1.60 \\
\hline OPA & 4.634 & 1.500 & 0.426 & 8.10 & 2.30 \\
\hline ASEJIRE & 3.232 & 0.462 & 0.131 & 5.00 & 2.00 \\
\hline PDD ERO & 3.822 & 0.765 & 0.217 & 5.70 & 2.50 \\
\hline OPA & 6.198 & 5.479 & 1.557 & 43.00 & 3.20 \\
\hline ASEJIRE & 4.462 & 0.500 & 0.142 & 6.40 & 3.30 \\
\hline ULL ERO & 0.934 & 0.228 & 0.0649 & 1.50 & 0.60 \\
\hline OPA & 1.232 & 0.358 & 0.102 & 2.00 & 0.40 \\
\hline ASEJIRE & 1.062 & 0.155 & 0.0441 & 1.60 & 0.80 \\
\hline LJL ERO & 2.158 & 0.251 & 0.0977 & 2.80 & 0.70 \\
\hline OPA & 2.112 & 0.925 & 0.263 & 3.60 & 0.60 \\
\hline ASEJIRE & 1.508 & 0.344 & 0.0713 & 3.20 & 1.60 \\
\hline LLW ERO & 0.968 & 0.300 & 0.0852 & 1.60 & 0.50 \\
\hline OPA & 1.228 & 0.267 & 0.0760 & 1.80 & 0.70 \\
\hline ASEJIRE & 1.008 & 0.158 & 0.0448 & 1.50 & 0.80 \\
\hline LLL ERO & 0.594 & 0.174 & 0.0495 & 1.10 & 0.30 \\
\hline OPA & 0.846 & 0.28 & 0.081 & 1.80 & 0.30 \\
\hline ASEJIRE & 0.504 & 0.0925 & 0.0263 & 0.70 & 0.30 \\
\hline PcFL ERO & 0.780 & 0.236 & 0.0672 & 1.30 & 0.30 \\
\hline OPA & 1.296 & 0.377 & 0.107 & 2.20 & 0.50 \\
\hline ASEJIRE & 0.780 & 0.156 & 0.0445 & 1.40 & 0.70 \\
\hline POD ERO & 3.616 & 1.022 & 0.290 & 6.20 & 1.60 \\
\hline OPA & 5.040 & 1.478 & 0.420 & 8.90 & 2.30 \\
\hline ASEJIRE & 4.070 & 0.508 & 0.144 & 6.10 & 3.20 \\
\hline CPL ERO & 0.814 & 0.245 & 0.0696 & 1.70 & 0.40 \\
\hline OPA & 1.320 & 0.419 & 0.119 & 2.40 & 0.60 \\
\hline ASEJIRE & 1.216 & 0.527 & 0.150 & 4.40 & 0.80 \\
\hline CPD ERO & 1.590 & 0.385 & 0.109 & 2.80 & 0.90 \\
\hline OPA & 2.456 & 0.846 & 0.240 & 4.20 & 1.10 \\
\hline ASEJIRE & 2.110 & 0.260 & 0.0738 & 3.00 & 1.50 \\
\hline
\end{tabular}


Oladimeji et al.: Morphological Characterization of Natural Populations of Sarotherodon galilaeus

\begin{tabular}{|c|c|c|c|c|c|c|}
\hline \multicolumn{2}{|c|}{$\begin{array}{l}\text { Morphometric } \\
\text { and Meristic } \\
\text { parameters }\end{array}$} & \multirow{2}{*}{$\begin{array}{l}\text { Mean } \\
1.744\end{array}$} & \multirow{2}{*}{$\begin{array}{l}\text { Std. } \\
\text { Deviation } \\
1.511\end{array}$} & \multirow{2}{*}{$\begin{array}{l}95 \% \text { C.I. } \\
\text { of mean }\end{array}$} & \multirow{2}{*}{$\begin{array}{c}\text { Max. } \\
12.00\end{array}$} & \multirow{2}{*}{$\begin{array}{l}\text { Min. } \\
1.00\end{array}$} \\
\hline LJW & ERO & & & & & \\
\hline & OPA & 2.766 & 3.036 & 0.863 & 23.00 & 0.90 \\
\hline & ASEJIRE & 1.744 & 0.225 & 0.0639 & 2.60 & 1.40 \\
\hline \multirow[t]{3}{*}{ PSL } & ERO & 1.520 & 0.233 & 0.0662 & 2.30 & 1.10 \\
\hline & OPA & 2.144 & 0.639 & 0.182 & 3.60 & 0.90 \\
\hline & ASEJIRE & 1.794 & 0.222 & 0.0630 & 2.40 & 1.10 \\
\hline \multirow[t]{3}{*}{ PAD } & ERO & 6.916 & 1.392 & 0.396 & 10.70 & 5.00 \\
\hline & OPA & 11.006 & 3.189 & 0.906 & 18.50 & 6.80 \\
\hline & ASEJIRE & 7.930 & 0.934 & 0.265 & 11.80 & 6.20 \\
\hline \multirow[t]{3}{*}{ PelD } & ERO & 3.842 & 0.816 & 0.232 & 6.10 & 2.30 \\
\hline & OPA & 6.056 & 1.645 & 0.467 & 10.40 & 3.40 \\
\hline & ASEJIRE & 4.488 & 0.656 & 0.186 & 6.80 & 3.20 \\
\hline \multirow[t]{3}{*}{ SLL } & ERO & 28.740 & 2.877 & 0.818 & 34.00 & 19.00 \\
\hline & OPA & 28.560 & 2.697 & 0.766 & 33.00 & 24.00 \\
\hline & ASEJIRE & 31.000 & 1.884 & 0.536 & 35.00 & 26.00 \\
\hline \multirow[t]{3}{*}{ DsS } & ERO & 16.200 & 0.452 & 0.128 & 17.00 & 15.00 \\
\hline & OPA & 15.900 & 0.364 & 0.104 & 17.00 & 15.00 \\
\hline & ASEJIRE & 16.280 & 0.454 & 0.129 & 17.00 & 16.00 \\
\hline \multirow[t]{3}{*}{ DsR } & ERO & 11.880 & 0.558 & 0.159 & 17.00 & 11.00 \\
\hline & OPA & 11.880 & 0.961 & 0.273 & 15.00 & 10.00 \\
\hline & ASEJIRE & 11.580 & 1.052 & 0.299 & 13.00 & 11.00 \\
\hline \multirow[t]{3}{*}{ GIR } & ERO & 19.460 & 3.632 & 1.032 & 25.00 & 10.00 \\
\hline & OPA & 24.140 & 2.356 & 0.670 & 31.00 & 18.00 \\
\hline & ASEJIRE & 22.860 & 1.485 & 0.422 & 29.00 & 18.00 \\
\hline \multirow[t]{3}{*}{ AFR } & ERO & 11.000 & 0.000 & 0.000 & 11.00 & 11.00 \\
\hline & OPA & 10.840 & 0.468 & 0.133 & 12.00 & 10.00 \\
\hline & ASEJIRE & 10.840 & 0.738 & 0.210 & 13.00 & 8.00 \\
\hline \multirow[t]{3}{*}{ AFS } & ERO & 3.000 & 0.000 & 0.000 & 3.00 & 3.00 \\
\hline & OPA & 3.000 & 0.000 & 0.000 & 3.00 & 3.00 \\
\hline & ASEJIRE & 3.000 & 0.000 & 0.000 & 3.00 & 3.00 \\
\hline
\end{tabular}

\section{Abbreviations:}

$\begin{array}{ll}\text { TL }= & \text { Total length } \\ \text { SL }= & \text { Standard length } \\ \text { HL }= & \text { Head length, } \\ \text { BD }= & \text { Body depth, } \\ \text { SNL }= & \text { Snout length } \\ \mathrm{CD}= & \text { Cheek depth } \\ \mathrm{EL}= & \text { Eye length } \\ \mathrm{DFL}= & \text { Dorsal fin length } \\ \mathrm{AFL}= & \text { Anal fin length } \\ \mathrm{LDS}= & \text { Length of last dorsal spine } \\ \mathrm{LAS}= & \text { Length of third anal spine } \\ \mathrm{PFL}= & \text { Pelvic fin length } \\ \mathrm{PDD}= & \text { Pre-dorsal Distance } \\ \mathrm{ULL}= & \text { Upper lip length } \\ \mathrm{LJL}= & \text { Lower jaw length }, \\ \mathrm{LLW}= & \text { Lower lip width } \\ \mathrm{LLL}= & \text { Lower Lip Length }\end{array}$

$\begin{array}{ll}\text { PECFL }= & \text { Pectoral fin length } \\ \text { POD }= & \text { Pre-orbital distance } \\ \text { CPL }= & \text { Caudal peduncle length } \\ \text { CPD }= & \text { Caudal Peduncle Depth } \\ \text { LJW }= & \text { Lower jaw width } \\ \text { PSL }= & \text { Pelvic spine length } \\ \text { PAD }= & \text { Pre-anal distance } \\ \text { PELD }= & \text { Distance of lower jaw to pelvic fin } \\ \text { SLL }= & \text { No. of scales on lateral line } \\ \text { DsS }= & \text { No. of Dorsal spine } \\ \text { DsR }= & \text { No. of Dorsal ray } \\ \text { GIR }= & \text { No. of Gill rakers } \\ \text { AFR }= & \text { No. of Anal fin ray } \\ \text { AFS }= & \text { No of Anal fin spine }\end{array}$




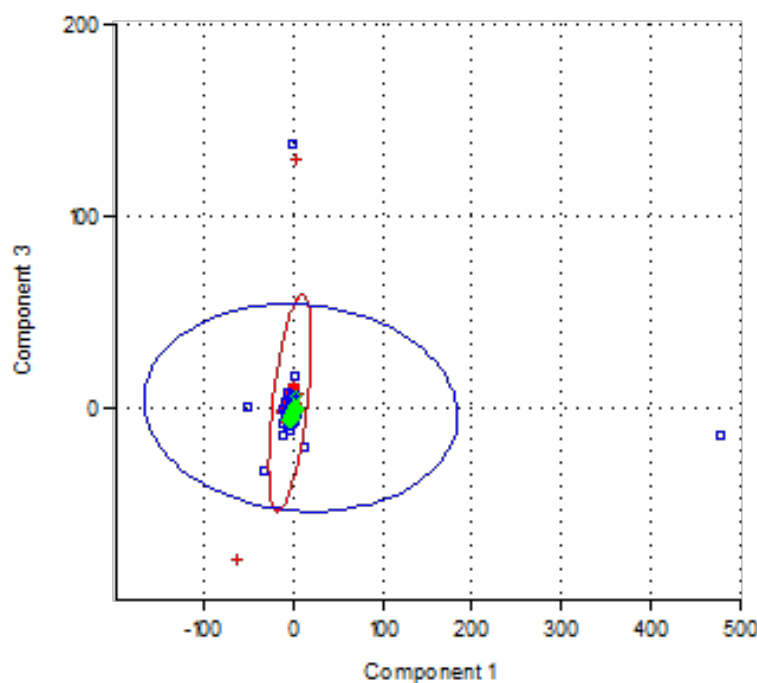

Figure 4: Principal Component Analysis Based on Morphometric Measurements of Sarotherodon galilaeus showing Overlap of Characters among the Three Populations

Note: Opa Reservoir (blue), Asejire Reservoir (green) and Ero Reservoir (red).

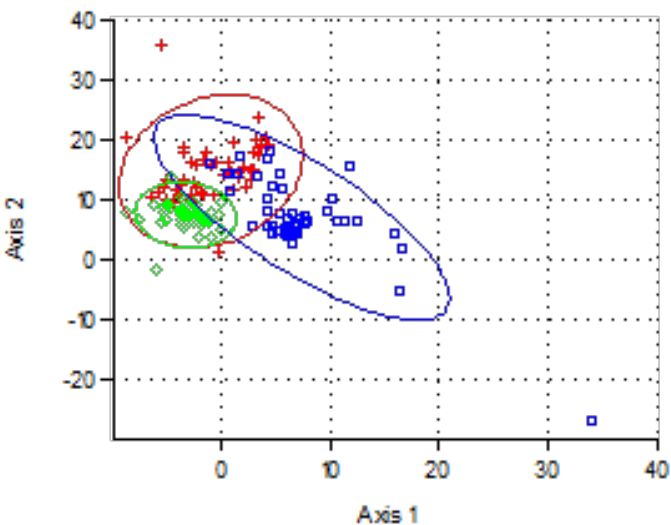

Figure 5: Canonical Variate Analysis (CVA)

Based on Morphometric

Measurements of Sarotherodon galilaeus

Note: Ero Reservoir (red), Opa Reservoir (blue) and Asejire Reservoir (green)

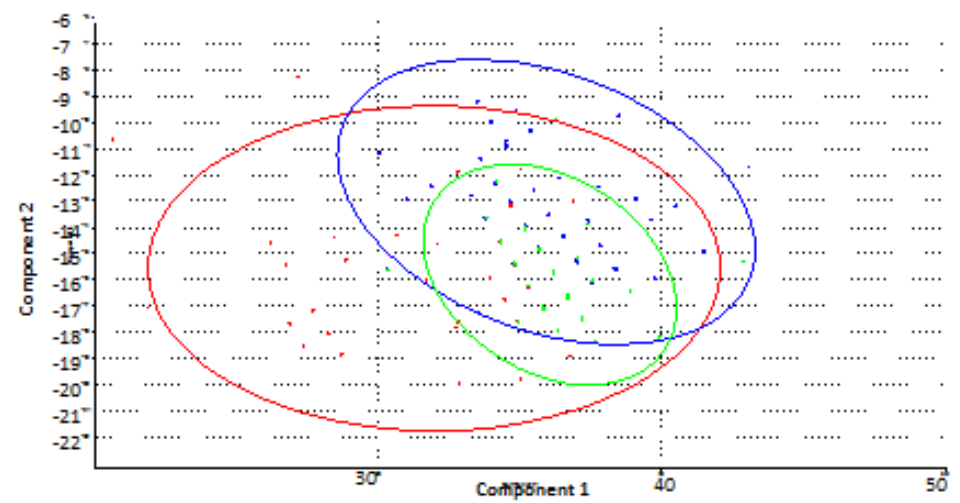

Figure 6: Principal Component Analysis based on 6 Meristic Counts of Sarotherodon galilaeus from the Three Populations

Note: Ero Reservoir (red), Opa Reservoir (blue) and Asejire Reservoir (green)

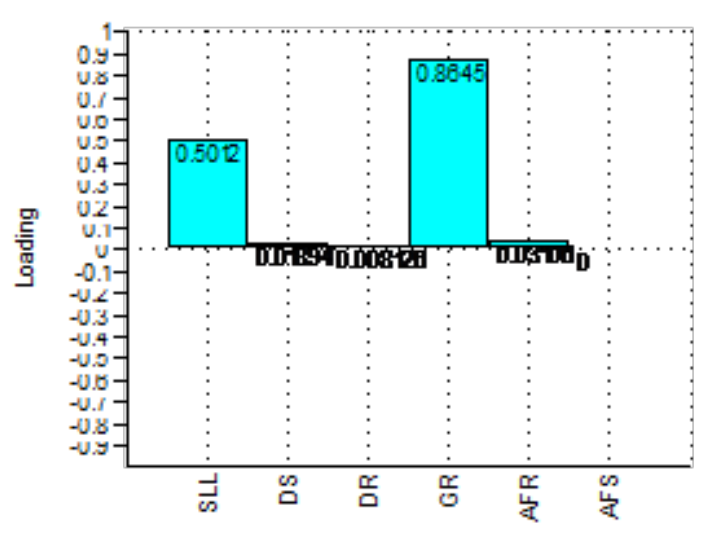

Figure 7: Respective Sarotherodon galilaeus Meristic Counts and their Loadings on Component1 of the Principal Component Analysis

\section{Abbreviations:}

SLL $=$ Scales on lateral line

$\mathrm{DR}=$ Dorsal ray

$\mathrm{AFR}=$ Anal fin ray
DS $=$ Dorsal spine

$\mathrm{GR}=$ Gill rakers

$\mathrm{AFS}=$ Anal fin spine 


\section{DISCUSSION}

Measurements of morphometric characters and meristic counts were employed in this study because they are considered to be dependable tools to characterize and identify fish species especially on the field where more detailed diagnostic tools such as biochemical and molecular markers are not available. Also, morphometric and meristic measurements are considered dependable tools because they are sensitive to environmental changes (Fryer and Iles, 1972).

The wide overlap of data observed among the morphometric measurements of $S$. galilaeus from the three reservoirs of study (Opa, Asejire and Ero) as revealed by the PCA implies that there are no statistically significant differences in the morphometric measurements of S.galilaeus across the three different reservoirs. Canonical Variate Analysis, however, was able to identify variants in the morphometric characters of some $S$. galilaeus species inhabiting Opa reservoir only; thus revealing intra-specific variation within the Opa reservoir population of $S$. galilaeus. Also, factor loadings based on Principal Component analysis identified dorsal fin length and number of gill rakers as the morphometric and meristic character respectively, which varied most among the three populations.

This may be a reflection of the difference in feeding environment, availability of different food types and prey in the different study areas. Also, the fish fauna in the three different reservoir varies; which means that the predators that the fishes are exposed to will also vary in the different environments. This observation can be justified by the fact that fishes are more susceptible to environmentally-induced morphological variation and they show greater variation in morphological characters both within and among populations than any other group of vertebrates (Winberger, 1992; Turan et al., 2006). Similarly, the intraspecific morphological variation observed in the Opa reservoir population of $S$. galilaeus as revealed by the Canonical Variate Analysis (CVA) confirms the report of Smith and Skulason (1996) that intra-population variation exist in fish species which could correlate with habitat choice as well as availability of food resources.
A general overlap of morphometric and meristic characters of $S$. galilaeus was observed in the three reservoirs of study, Opa, Asejire and Ero reservoirs (Osun, Oyo and Ekiti states respectively). The observed overall morphological relatedness may be as a result of similar climatic conditions in these three reservoirs. This is consistent with the report of Carvalho (1993) that if localized populations inhabit similar environments, they may fail to display great heterogeneity in phenotypic or genetic traits. The findings of this study is in contrast to that of Oladimeji and Olaosebikan (2017) who reported that Tilapia zillii population from Ero and Asejire reservoirs were morphologically different, while the T. zillii population from Opa reservoir shares some morphological similarities with both Ero and Asejire reservoirs.

Similarly, Omoniyi and Agbon (2008) reported morphometric and meristic variations in Sarotherodon melanotheron collected from brackish and fresh water habitats in southwestern, Nigeria. They suggested that the morphological variations could be as a result of difference in the temperature, salinity and substratum in the two water bodies. Olopade et al. (2018) also reported significant morphological differences between a freshwater and brackish water population of Coptodon guineensis in Rivers state, Nigeria and concluded that the two populations are phenotypically separable. Solomon et al. (2015) noted that morphological variations among different populations of the same species of fish are usually indicative of adaptations to prevailing environmental conditions which may be unique to each population. Chukwuka et al. (2019) reported large morphological differences between Sarotherodon galilaeus and Oreochromis niloticus in Lake Geriyo, northeastern Nigeria. They noted that the observed morphological differences are an indication that the species had adapted to different spatial and vertical distributions within the lake.

In conclusion, morphological similarities were observed among $S$. galilaeus populations occupying Opa, Asejire and Ero reservoirs. These results established homogeneity in morphology among populations of $S$. galilaeus inhabiting the three different reservoirs. This implies that the 
populations are phenotypically inseparable and there are no morphotypes of this species in the selected study areas.

\section{REFERENCES}

Akinbuwa, O. and Adeniyi, I. F. 1996. Seasonal variation, distribution and interrelationships of rotifers in Opa Reservoir, Nigeria. African Journal of Ecology, 34: 351-363.

Allendorf, F. W., Ryman, N. and Utter, F. M. 1987. Genetics and Fishery Management. In Population Genetics and Fishery Management, University of Washington. pp. 1-9.

Ayodele, H. A. 1979. The influence of some physico-chemical factors on the composition, abundance and character of zooplankton in some Lakes in Osun River Basin. M. Sc. Thesis, University of Ife, Ile-Ife, Nigeria

Bailey, K. M. 1997. Structural dynamics and ecology of flatfish populations. Journal of Sea Research, 37(3-4):269-280.

Bolnick, D. I., Svanback, R., Fordyce, J. A., Yang, L. H., Davis, J. M, C. Darrin Hulsey, C. D. and Forister, M. L. 2003. The ecology of individuals: Incidence and implications of individual specialization. American Naturalist, 161:1-28.

Carvalho, G. R. 1993. Evolutionary aspects of fish distribution: genetic variability and adaptation. Journal of Fish Biology, 43: 5373.

Chukwuka, A. V., Adebowale, A. H., Adekolurejo, O. A. 2019. Morphological differences and trophic niche breadth of Sarotherodon galilaeus and Oreochromis niloticus from the freshwater Lake Geriyo, North-Eastern Nigeria. Croatian Journal of Fisheries, 77, 19-32.

Dayton, G. H., Saenz, D., Baum, K. A., Langerhans, R. B. and DeWitt, T. J. 2005. Body shape, burst speed and escape behavior of larval anurans. Oikos, 111: 582-591.

Deesri, U., Cavin, L., Claude, J., Suteethorn, V. and Yuangdetkla, P. 2009. Morphometric and taxonomic study of a ray-finned fish assemblage (Lepidotes buddh abutrensis, Semionotidae) from the late Jurassic- earliest Cretaceous of NE Thailand. Geological Society of London Special Publication, 315: 115-124.

DeWitt, T. J., Robinson, B. W. and Wilson, D. S. 2000. Functional diversity among predators of a freshwater snail imposes an adaptive trade-off for shell morphology. Evolutionary Ecology Research, 2: 129-148.

DeWitt, T. J and Scheiner, S. M. 2004. Phenotypic Plasticity. Functional and Conceptual Approaches. New York: Oxford University Press.

Dunz, A. and Schliewen, U. K. 2010. Description of a Tilapia (Coptodon) Species Flock of Lake Ejagham (Cameroon), (Perciformes, Cichlidae). Spixiana, 33(2): 251-280.

Froese, R. and Pauly, D. 2014. "Sarotherodon galilaeus" in Fish Base. July 2014 version

Fryer, G. and Iles, T. D. 1972. The Cicblid Fish of the Great Lakes of Africa. Oliver and Boyd, Edinburgh 641 pp.

Hammer, O., Harper, D. A. T. and Ryan, P. D. 2001. PAST: Paleontological Statistics Software Package for Education and Data Analysis. Palaeontologia Electronica, 4(1):50-56.

Ihssen, P. E., Booke, H. E., Casselman, J. M., Glade, M. C., Payne, N. R. and Utter, F. M. 1981. Stock identification: materials and methods. Canadian Journal of Fisheries and Aquatic Sciences, 38: 1838- 1855.

Johansson, F. and Wahlstrom, E. (2002) Induced morphological defence: evidence from whole-lake manipulation experiments. Canadian Journal of Zoology, Revue Canadienne de Zoologie, 80:199-206.

Khayyami, H., Zolgharnein, H., Salamat, N. and Movahedinia, A. 2015. Morphological Variability of Liza klunzingeri (Day, 1888) from Bandar Abbas Port and Qeshm Island in North eastern Persian Gulf. Journal of Fisheries and Aquatic Sciences, 10: 191-198.

Lattuca, M. E., Ortubay, S., Battini, M. A., Barriga, J. P. and Cussac, V. E. 2007. Presumptive environmental effects on body shape of Aplochiton rebra (Pisces, Galaxiidae) in northern Patagonian lakes. Journal of Applied Ichthyology, 23:25-33. 
Lindsey, C. C. 1988. Factors Controlling Meristic Variation. In: Fish Physiology, Hoar, W.S. and D.J. Randall (Eds.). Academic Press, London, pp: 197-274.

Oladimeji, T. E. and Olaosebikan, T. O. 2017. Morphological variability of Tilapia zillii (Gervais, 1848) from selected reservoirs in Southwestern, Nigeria. Ife Journal of Science, 19(1): 15-25.

Oladimeji, T. E., Awodiran, M. O. and Komolafe, O. O. 2015. Genetic differentiation studies among natural populations of Tilapia zillii. Notulae Scientia Biologica, 7(4):423-429.

Olopade, O. A., Dienye, H. E., Jimba, B. and Bamidele, N. A. 2018. Observations on the morphometric and meristic characters of Guinean Tilapia, Coptodon guineensis (Günther, 1892) (Family: Cichlidae) from the Buguma Creek and the New Calabar River in Nigeria. Jordan Journal of Biological Sciences, 11:247-255.

Omoniyi, I. T. and Agbon, A. O 2008. Morphometric variations in Sarotherodon melanotheron (Pisces: Cichlidae) from brackish and fresh water habitats in south-western Nigeria. West African Journal of Applied Ecology, 12:1-5.

Omoniyi, O. J. and Basorun, J. O. 2013. Spatial Analysis of Dam Water Distribution in Ero Region, Nigeria. European International Journal of Science and Technology, 2(5): 87-95.

Paugy, D., Leveque, C. and Teugels, G. G. 2003. The fresh and brackish water fishes of West Africa Volume I and II. IRD Editions. Publications scientifiques. Du museum. 457 and 815pp.

Phillips, B. L. and Shine, R. 2004. Adapting to an invasive species: Toxic cane toads induce morphological change in Australian snakes. Proceedings of the National Academy of Sciences of the United States of America, 101: 17150-17155.

Pinheiro, A. Teixeira, C. M., Rego, A. L. Marques, J. F. and Cabral, H. N. 2005. Genetic and morphological variation of Solea lascaris (Risso, 1810) along the Portuguese coast. Fisheries Research, 73: 67-78.

Price, T. 1987. Diet variation in a population of Darwin's finches. Ecology, 68: 1015-1028.
Reist, J. D. 1985. An empirical evaluation of several univariate methods that adjust for size variation in morphometric data. Canadian Journal of Zoology, 63: 14291439.

Smartt, R. A. and Lemen, C. 1980. Intrapopulation morphological variation as a predictor of feeding behaviour in deer mice. American Naturalist, 116: 891-894.

Smith, T. B. and Skulason, S. 1996. Evolutionary significance of resource polymorphism in fishes, amphibians and birds. Annual Review of Ecology, Evolution, and Systematics, 27:111-133.

Solomon, S. G., Okomoda, V. T. and Ogbenyikwu, A. I. 2015. Intraspecific morphological variation between cultured and wild Clarias gariepinus (Burchell) (Clariidae, Siluriformes). Archives of Polish Fisheries, 23: 53-61.

Spoljaric, M. A. and Reimchen, T. E. 2007. 10,000 years later: evolution of body shape in Haida Gwaii three-spined stickleback. Journal of Fish Biology, 70:1484-1503.

Stearns, S. C. 1983. A natural experiment in lifehistory evolution: Field data on the introduction of mosquitofish (Gambusia affinis) to Hawaii. Evolution, 37: 601-617.

Suneetha, G. K. B. and Damayanthi, H. G. B. N. 2008. Morphometric and isozyme confirmation for species level divergence between Puntius dorsalis (Pisces: Cyprinidae) and its presumed red-fin variety in Sri Lanka. Rubuna Journal of Science, 3:25-34.

Swain, D. P. and Foote, C. J. 1999. Stocks and Chameleons: The use of phenotypic variation in stock identification. Fisheries Research, 43: 1123-1128.

Tudela, S. 1999. Morphological variability in a Mediterranean, genetically homogeneous population of the European anchovy, Engraulis encrasicolus. Fisheries Research, 42: 229-243.

Turan, C., Oral, M., Ozturk, B. and Duzgunes, E. 2006. Morphometric and meristic variation between stocks of bluefish (Pomatomus saltatrix) in the Black, Marmara, Aegean and northeastern Mediterranean seas. Fisheries Research, 79: 139-147. 
096 Oladimeji et al.: Morphological Characterization of Natural Populations of Sarotherodon galilaeus

Webster, M. M., Atton, N., Hart, P. J. B. and Ward, Winberger, P. H. 1992. Plasticity of fish body A. J. W. 2011. Habitat-specific morphological variation among three spine sticklebacks (Gasterosteus aculeatus) within a drainage basin. Plos One, 6(6): e21060. doi:10.1371/journal.pone.0021060. shape. The effects of diet, development, family and age in two species of Geophagus (Pisces: Cichlidae). Biological Journal of the Linnean Society, 45: 197-218. 